\title{
The Applied Strategies for Fiscal Policy Adjustments: The Situation of Ex-Communist Countries from EU27
}

\author{
Laura Obreja Braşoveanu ${ }^{1}$, Florentina Olivia Bălu ${ }^{1,2}$, Bernard Morard $^{2} \&$ Iulian Braşoveanu ${ }^{1}$ \\ ${ }^{1}$ Bucharest University of Economic Studies, Romania \\ ${ }^{2}$ Unimail Geneve, Switzerland \\ Correspondence: Laura Obreja Braşoveanu, Bucharest University of Economic Studies, Piața Romană, Nr. 6, \\ sector 1, Bucureşti, România. Tel: 40-72-268-3451. E-mail: laura_obreja@yahoo.com
}

Received: March 17, 2015

Accepted: April 23, 2015

Online Published: June 25, 2015

doi:10.5539/ijef.v7n7p138

URL: http://dx.doi.org/10.5539/ijef.v7n7p138

\begin{abstract}
This article aims to identify the applied strategies for discretionary fiscal changes-fiscal adjustments and fiscal expansions-for the period 1990-2011 in ex-communist European Union countries. Using data for fiscal adjustments (improvement of the budget balance) and for fiscal expansions (deterioration of the budget balance), there are analysed the strategies that led to this change in fiscal policy indicators and their impact on the economic activity.

The database contains 1990-2011 period and consists in macroeconomic indicators which reflect the fiscal policy (public revenues, public expenditures, public budget balance, general government consolidated gross debt), economic growth (GDP per capita, output gap) and fiscal adjustment process (size, proportion obtained by decreasing expenditure to GDP, proportion obtained by rising revenues to GDP, and dummy variables for need, success, gradual, expenditure based).

In order to identify the characteristics of the fiscal policy adjustments and their effects on the economic growth, we apply cluster analysis, graphic analysis, statistical indicators, and logit models. The obtained results of these methods are useful for evaluating the strategies used for diminishing / extending the deficit and to identify the determinant factors for the adjustment's success.
\end{abstract}

Keywords: public revenues, public expenditures, fiscal policy, fiscal adjustment, fiscal expansions

\section{Introduction}

\subsection{Introduce the Problem}

One of the common problems of most countries from European Union is the high budget deficit. As a result of the fiscal response to the financial crisis of 2007-2009, the European Countries have experienced the largest increases in deficits and debt accumulation (Alessina \& Ardagna, 2009). This problem is also one of the main problems of the new member states (ex-communist countries) of EU which have to face serious fiscal problems and to solve them through fiscal adjustments.

The present fiscal and economic context sustains the need for fiscal adjustment, which may be reached by public revenues' rise or by public expenditures' decline. According to Alesina (2010), fiscal adjustments through spending cuts have the highest chance of success. Fiscal adjustments would not have large social cost if they are accompanied by welfare reforms when needed.

The current economic situation at national and international level highlights the need for identifying the adequate economic measures, capable to bring savings on an increasing trend and to restore public budget balance, creating thus the prerequisites for a sustainable economic development in the medium-term (Câmpeanu, 2011; Stoian, 2011).

\subsection{Research Objective}

This paper has the research objective to identify the strategies for discretionary fiscal policy changes (fiscal adjustments, fiscal expansions) for the case of the ex-communist European Union countries, in the period 1990-2011. Using data for fiscal adjustments (improvement of the budget balance) and for fiscal expansions (deterioration of the budget balance), there are analysed the strategies that led to the fiscal position's change 
(reducing/increasing the deficit) and their impact on economic growth. Because of the necessity of the fiscal adjustments, we intend also to detect if there is an "optimal" fiscal adjustment, taking into consideration the reaction of economic growth to the fiscal adjustment.

Using specific methods such as cluster analysis, regressions, logit models, graphic analysis our study aims to assess the strategies used for reducing the deficit and to identify the determinant factors for the fiscal adjustment episodes' success-the necessity, the size, the composition of the fiscal adjustment, and the expansionary effects of fiscal adjustments.

The obtained results permit us to conclude that sustainable deficit reduction is obtained through significant fiscal adjustments.

\subsection{Paper Structure}

Starting from the proposed research objective we organized our paper into two main parts.

The first part is a theoretical one and it reviews the main findings of previous studies on fiscal adjustment. There are identified the key definitions of the main concepts such as: fiscal adjustment, successful fiscal adjustment and expansionary fiscal adjustment.

The second part is an empirical one and presents the empirical study on the fiscal position-fiscal expansion and fiscal adjustment episodes-in ex-communist countries of European Union (UE10-Bulgaria, Czech Republic, Estonia, Hungary, Latvia, Lithuania, Poland, Romania, Slovakia, and Slovenia) in comparison with the others countries of European Union (UE17 from all EU27) during 1990-2011. First of all, we present the hypotheses and variables of our study and after that we identify the applied strategies for fiscal policy and their consequences on the economic growth.

\section{Literature Review}

There is a rich literature that speaks about the mechanism and the consequences of fiscal adjustments. Without doing an exhaustive list, we try to mention several of the most important researches regarding the fiscal adjustment subject. In this section we present the definition for fiscal adjustment in the context of the classification of fiscal policy, the definition of the fiscal adjustment's success defined in correlation with the sustainability of deficit decline.

\subsection{Fiscal Adjustment-Definitions}

- Alesina, Perotti (1995) used the changes of the budget deficit (called fiscal impulse, denoted by FI, to define the stance for fiscal policy:

(a) neutral, if the FI is in the range $(-0.5 \% ;+0.5 \%)$;

(b) relaxed, if FI is in the range $(+0.5 \% ;+1.5 \%)$;

(c) very relaxed, if FI is greater than $1.5 \%$;

(d) restrictive (with moderate adjustments), if FI is in the range $(-1.5 \% ;-0.5 \%)$;

(e) very restrictive (with strong adjustments), if FI is less than $-1.5 \%$.

- Purfield (2003) considered fiscal policy as being very restrictive if there is an improvement of budget primary balance/GDP by at least $1.5 \mathrm{pp}$. in a year or at least $1.25 \mathrm{pp}$. in at least two consecutive years.

- Alesina, Perotti (1995) redefined the stance of fiscal policy, considering the mean $(\mu)$ and the standard deviation $(\sigma)$ of fiscal impulse:

(a) neutral if the FI is in the range $(-\mu \mathrm{i}-0.5 \sigma \mathrm{i} ;-\mu \mathrm{i}+0.5 \sigma \mathrm{i})$;

(b) relaxed, if FI is in the range $(\mu \mathrm{i}+0.5 \sigma \mathrm{i} ; \mu \mathrm{i}+\sigma \mathrm{i})$;

(c) very relaxed, if FI is greater than $\mu \mathrm{i}+\sigma \mathrm{I}$;

(d) restrictive (with moderate adjustments), if FI is in the range ( $\mu \mathrm{i}-\sigma \mathrm{i} ; \mu \mathrm{i}-0.5 \sigma \mathrm{i})$;

(e) very restrictive (with strong adjustments), if FI is less than $\mu \mathrm{i}-\sigma \mathrm{i}$.

\subsection{Fiscal Adjustment's Success-Definitions}

- Alesina (1995) defined the successful fiscal adjustment as the situation in which a strong adjustment determines, after three years, a decrease of the ratio gross debt to GDP of/by at least $5 \mathrm{pp}$. comparing to the year of fiscal adjustment. 
- Alesina (1996) redefined the successful fiscal adjustment as the situation in which strong adjustment is characterized by the following conditions: (i) in the next three years after the adjustment, the cyclically adjusted primary deficit is on average $2 \%$ p.p. lower compared to last year of the restrictive fiscal policy, (ii) in the third year after the adjustment, the debt to GDP is 5 p.p. below the level registered in last year of the adjustment.

- Purfield (2003) considered that a fiscal adjustment episode is successful if the average of the general government balance two years after is at least $2 \mathrm{pp}$. lower than two years before the adjustment.

\subsection{Expansionary Fiscal Adjustment-Definition}

- Purfield (2003) considered that a fiscal adjustment episode is expansionary if, in the adjustment period and in the next two years, the average growth rate of real GDP is more than one standard deviation over the average growth rate throughout the period.

- Alesina (2010) defined a fiscal adjustment as expansionary if in the year of the adjustment, and in the two following years, growth is above the average in the sample. An expansionary episode is "an episode in which growth is not only above average, but also it is in the top 25 per cent of the sample ... the Economist incorrectly characterizes our results as if we had implied that most fiscal adjustments cause economic booms. Instead, what we demonstrate is that fiscal adjustments based mostly on spending cuts sometimes are associated with levels of growth well above sample average, even on impact. We certainly agree that various accompanying policies, such as monetary easing, supply side reforms and, devaluations may help".

\subsection{Relevant Literature}

Giavazzi and Pagano (1990) were the pioneers which proved that „fiscal adjustments large, decisive and on the spending side could be expansionary. They brought as argument the example of Ireland (1987-1989) and Denmark (1986-89). From theoretical point of view, "expansionary effects of fiscal adjustments can go through both the demand and the supply side" (Alessina, 2010). Regarding the demand, a fiscal adjustment may be expansionary if agents consider that the fiscal adjustment determines a change in regime that "eliminates the need for larger, maybe much more disruptive adjustments in the future" (Blanchard, 1990).

McDermott, Wescott (1996) concluded that the size of the adjustment is very important for its success: Giavazzi, Pagano (1996), using a methodology based on estimating the consumption function, showed that only significant and persistent fiscal adjustments are expansionary, explaining by the wealth and credibility effects. Symansky, Bertolini, Razin (1995), studying the effects of fiscal adjustment episodes in the case of G7 countries, demonstrated that adjustments have short-term costs by the production decline, but there are long-term benefits.

Other empirical studies regarding the fiscal adjustment sustained the same idea "Fiscal adjustments do not always cause recessions. On the contrary, fiscal consolidations prompted by a fiscal crisis and achieved by trimming government spending often have expansionary effects" (Alesina, Perotti, \& Tavares, 1998). Cutting government wage and reduction in transfer payments may guarantee relatively durable fiscal consolidation, whereas "tax hikes and cuts in government investment apparently are reversed more quickly" (Alesina, Perotti, \& Tavares, 1998).

Hughes and McAdam (2001), using stochastic simulations, analysed the probability distribution of a country's deficit ratio under different monetary and fiscal policies and they concluded that "fiscal targets may have to be country specific and conservative, and that fiscal policy has to be forward looking to keep the probability of excessive deficits below acceptable limits" (Hughes \& McAdam, 2001).

Von Hagen, Hughes, and Strauch (2002) argued that for advanced OECD economies "consolidation fatigue" and the quality of fiscal consolidations are important determinants of their longevity, but for the European Union countries they suggested that the „Maastricht process contributed much to the fiscal consolidations”.

Purfield (2003) identified factors that affect the likelihood of successful adjustment: the size of the consolidation effort (considering that significant adjustment episodes are supposed to be more successful for deficit reduction, because they are interpreted as a signal of regime change, which imply credibility and irreversibility of the fiscal policy), the structure of the fiscal adjustment (adjustment based on expenditure cuts are more likely to be sustainable in deficit reduction process), the duration of the fiscal adjustment (the fiscal adjustment is more credible and less likely to be reversible if it is implemented in a longer period; even if there are taken into consideration the political implications, the adjustment cost is smaller if the burden is extended in several years).

Ardagna (2004) concluded that the composition of fiscal policy is a crucial element for growth and the labour market has an important contribution for the transmission of fiscal policy shocks, but the success of fiscal 
adjustments in decreasing the debt-to-GDP ratio depends on the size of the fiscal contraction and less on its composition. He also suggested that successful and expansionary fiscal contractions are not the result of accompanying expansionary monetary policy or exchange rate devaluations.

Furthermore, there were other studies that asked and answered to question „when do fiscal adjustments normally occur?" They found that "it is more likely to occur when times of crisis occur, when new governments take office, when governments are "strong" (governments with a large majority), and when the executive branch faces fewer constraints" (Alesina, Ardagna, \& Trebbi, 2006).

Regarding the possible political cost of the fiscal adjustment, Alesina, Carloni, and Lecce (2011) examined the impact of fiscal adjustment on voters decision. The study results did not confirm the hypothesis that those governments that make decisions for a significant and rapid decrease of the budget deficit are penalized in future elections by the electorate.

Considering the impact of fiscal adjustment on the economic activity, there are explanations for a negative effect. Recently, Alesina (2010) concluded that a fiscal adjustment episode does not generate economic recession, because it prevents the necessity for stronger adjustments in the future. Fiscal stimuli based on tax decrease are more likely to promote economic growth, comparing with those based on spending rise (Alesina, 2009). Mulas-Granados, Baldacci, Clements, and Gupta (2004) also examined the short-term impact of various fiscal adjustment strategies on economic activity. The impact depends on the fiscal adjustment's composition.

Regarding the factors of fiscal adjustments' success (going back to Alesina \& Perotti, 1995), there were identified other more studies which suggested that consolidations performed on "spending-based" adjustments (cutting spending) are more successful comparing with those based on revenue increase, especially in the case of cutting transfers, and diminishing public wages (Kumar, Leigh, \& Plekhanov, 2007; Broadbent \& Daly, 2010; Stehn, 2010; Alesina \& Ardagna, 2010).

Obreja Braşoveanu (2011) studied the determinant factors of fiscal adjustment success for the European Union countries and found the need, the size and the composition of the fiscal adjustment as being the fundamental factors for the successful adjustment. The significant fiscal adjustments lead to sustainable deficit reduction, while the composition of fiscal adjustments through policies based on public expenditure or revenues does not significantly influence the probability of success".

Stehn, Hatzius, Wilson, and Carlson (2011) argued that countries are more likely to achieve sustained adjustments if there are higher initial deficits and if the adjustment focuses on spending cuts. Regarding the European countries with high budget deficits and debts, "a credible consolidation that reduces bond spreads can act to minimize the negative impact of consolidation on GDP growth. Where the adjustment is very front-loaded but fails to ease market tensions, yields remain elevated and GDP growth suffers, and market scepticism is vindicated" (Nielsen, 2011). There has to be taken delicate adjustment in order to balance the fiscal position around the world-acting too slowly is not sufficient, while acting too quickly may stumble the economy (Stehn, Hatzius, Wilson, \& Carlson, 2011).

\section{Empirical Research}

In this part of our paper, we define the database, we select the variables for fiscal policy, economic growth indicators, we construct fiscal adjustment indicators and dummy variables which characterize the fiscal adjustment strategies. In order to emphasize the common features of the ex-communist countries regarding the fiscal policy we conduct a cluster analysis; we identify the necessity for fiscal consolidation considering the signals from deficit public budget deficit in GDP and general government consolidated gross debt in GDP; we identify the periods of fiscal adjustment and fiscal expansions in ex-communist countries and in the developed EU countries and analyze their characteristics. For identifying the determinant factors of fiscal adjustment episodes' success (the necessity, the size, the composition) we use logit models for both groups of countries.

\subsection{Database}

The database contains annual data for the period 1990-2011 and it consists on ex-communist countries from European Union: BG, CZ, EE, HU, LV, LT, PL, RO, SK, SI, and this database is denoted as 10EU. In order to have a benchmark and to analyze the behaviour of these economies in the European context, we also use data for the other EU countries: AT, BE, CY, DK, FI, FR, DE, EL, IE, IT, LU, MT, NL, PT, ES, SE, UK, and this database is denoted as 17EU. The overall 27 countries from European Union are denoted as EU27.

In order to realise our econometrical analysis we used the following variables with their abbreviation:

Variables for fiscal indicators (data source: AMECO): 
bal $=$ public budget balance in GDP;

exp $=$ public expenditures in GDP;

rev $=$ public revenues in GDP;

$d e b t=$ general government consolidated gross debt in GDP.

Economic growth indicators (data source: AMECO):

$g d p p c=$ GDP per capita in constant price at PPS;

outputgap $=($ GDP current-GDP potential $) /$ GDP potential .

Variables for fiscal and economic growth indicators' change (own calculation):

$d x=$ absolute annual change of variable $\mathrm{x}$;

used for the following indicators:

$d b a l$-measuring the change in public budget balance in GDP, representing the size indicator;

dexp-measuring the change in public expenditures in GDP;

drev-measuring the change in public revenues in GDP;

$d d e b t$-measuring the change in general government consolidated gross debt in GDP;

$d p x=$ relative annual change of variable $\mathrm{x} ;$

$d p g d p p c=$ relative change of GDP per capita in constant price at PPS $=$ real growth rate.

Fiscal adjustment indicators (own calculation):

size $=$ fiscal adjustment's size $=$ change in budget balance $=d b a l$;

exp_contrib = part of fiscal adjustment obtained by decreasing expenditure to GDP (- delta public expenditure)/delta balance $=-\operatorname{dexp} / \mathrm{dbal}$;

rev_contrib $=$ proportion of fiscal adjustment achieved by increasing the revenues to GDP $=$ delta public revenue $/$ delta balance $=d r e v / d b a l$.

Dummy variables (own definition):

need_deficit = dummy variable for the need of fiscal adjustment signalled by the deficit, defined by the condition that the deficit on GDP is more than $3 \%$ in the previous year;

The construction of this dummy variable has the following logic:

need_deficit $=1$, if $b a l<-3 \%$ in the previous year, 0 otherwise;

need_debt $=$ dummy variable for the the need of fiscal adjustment signalled by the debt, defined by the condition that the public debt on GDP is more than $60 \%$ in the previous year.

The construction of this dummy variable has the following logic:

need debt $=1$, if $d e b t>60 \%$ in the previous year, 0 otherwise;

success = dummy variable for the successful characteristics of fiscal adjustment, defined by the condition that the next year after the adjustment the deficit is smaller than the deficit in the previous year;

The construction of this dummy variable has the following logic:

success $=1$, if bal after one year $>$ bal in the previos year, 0 otherwise;

dbal_dexp = dummy variable for the composition of the fiscal adjustment (based on expenditure cuts), defined by the situation that the deficit reduction is obtained by a more decrease of the public expenditures;

The construction of this dummy variable has the following logic:

dbal_dexp $=1$, if the decrease of the public expenditures is greater than the increase of the public revenues, 0 otherwise.

gradual $=$ dummy variable for the gradual characteristics of the fiscal adjustment, this gradualism being defined by the condition that the next year after the adjustment the deficit is smaller.

The construction of this dummy variable has the following logic:

need_deficit $=1$, if $b a l<-3 \%$ in the previous year, 0 otherwise. 


\subsection{Research Methodology}

In order to determine if the ex-communist countries have a common patern regarding fiscal policy and economic growth, we perform a cluster analysis. For emphasizing the necessity for fiscal adjustment, we identify the cases in which there have to be taken measures for fiscal adjustment-signalled by the public budget deficit in GDP (greater than 3\%), and signalled by the general government consolidated gross debt in GDP (greater than 60\%).

We define fiscal policy stances considering the changes of public budget deficit: very relaxed (very expansionary), relaxed, neutral, restrictive (moderate adjustments), very restrictive (strong adjustments); for each type of fiscal policy we determine the average values for the indicators, in order to identify the specific characteristics.

For determining the explanatory factors for the fiscal adjustment's success we perform several logit models on both groups of countries.

\subsection{Results and Interpretations}

In the following tables there are four clusters the EU27 countries, depending on the average values of public budget balance in GDP, general government consolidated gross debt in GDP, GDP per capita in constant prices at purchasing power standard (Table 1) and depending on the average values of absolute change (pp) in public budget balance in GDP, in general government consolidated gross debt in GDP and values of real GDP growth rate (Table 2).

Table 1. Cluster analysis for UE27 using average values for balance, debt and gdppc-four clusters

\begin{tabular}{lllll}
\hline cluster & $\boldsymbol{b a l}$ & $\boldsymbol{d e b \boldsymbol { t }}$ & $\boldsymbol{g} \boldsymbol{d} \boldsymbol{p p \boldsymbol { c }}$ & \\
\hline 1 & -5.36 & 108.03 & 22.567 & $\mathrm{BE}, \mathrm{EL}, \mathrm{IT}$ \\
2 & -3.14 & 22.00 & 13.986 & $\boldsymbol{C Z}, \boldsymbol{E} \boldsymbol{E}, \boldsymbol{L} \boldsymbol{V}, \boldsymbol{L} \boldsymbol{T}, \boldsymbol{R} \boldsymbol{O}, \boldsymbol{S K}, \boldsymbol{S \boldsymbol { I }}$ \\
3 & -3.02 & 56.35 & 21.150 & AT, $\boldsymbol{B} \boldsymbol{G}, \mathrm{CY}, \mathrm{DK}, \mathrm{FI}, \mathrm{FR}, \mathrm{DE}, \boldsymbol{H U}, \mathrm{IE}, \mathrm{MT}, \mathrm{NL}, \boldsymbol{P L}, \mathrm{PT}, \mathrm{ES}, \mathrm{SE}, \mathrm{UK}$ \\
4 & 1.94 & 8.13 & 50.697 & LU \\
\hline
\end{tabular}

The previous table sustains the common characteristics of the ex-communist countries 10EU. Using cluster analysis for constructing four cluster, most of the 10EU countries are grouped in the second cluster, with a relatively high level of budget deficit in GDP (central value of the cluster for $b a l=-3.14$ ), a low level of general government consolidated gross debt in GDP (central value of the cluster for debt $=22.00$ ) and the smallest level of GDP per capita in constant prices at purchasing power standard (central value of the cluster for $g d p p c=$ 13.986). The exceptions are BG, HU, and PL which are grouped in the third cluster, with a lower level of the public deficit, but a greater level of debt and gdppccppps.

Table 2. Cluster analysis for UE27 using average values for dbal, ddebt, dpgdppc-four clusters

\begin{tabular}{lllll}
\hline cluster & dbal & ddebt & dpgdppc & \\
\hline 1 & -0.06 & 1.69 & -4.42 & $\boldsymbol{C Z}, \boldsymbol{L} \boldsymbol{V}, \boldsymbol{L T}$ \\
2 & 0.17 & 2.05 & 0.66 & $\mathrm{CY}, \mathrm{FI}, \mathrm{FR}, \mathrm{DE}, \mathrm{EL}, \mathrm{IT}, \mathrm{MT}, \mathrm{PT}, \boldsymbol{R} \boldsymbol{\boldsymbol { O }}, \boldsymbol{S K}, \boldsymbol{S I}, \mathrm{ES}, \mathrm{UK}$ \\
3 & 0.34 & -0.24 & 0.51 & AT, BE, DK, $\boldsymbol{E} \boldsymbol{E}, \boldsymbol{H U}, \mathrm{IE}, \mathrm{LU}, \mathrm{NL}, \boldsymbol{P L}, \mathrm{SE}$ \\
4 & 0.45 & -6.57 & -3.18 & $\boldsymbol{B G}$ \\
\hline
\end{tabular}

The results presented in Table 2 sustain the different characteristics of the ex-communist countries 10EU. Using cluster analysis for constructing four clusters, there are showed the differences between the dynamic for the ex-communist countries. Some of the 10EU countries (i.e. CZ, LV, LT) are grouped in the first cluster, with a decrease of public deficit in GDP (central value of the cluster for $d b a l=-0.06$ ), a relatively high increase of the general government consolidated gross debt in GDP (central value of the cluster for the $d d e b t=1.69$ ) and the highest real GDP decrease rate (central value of the cluster for the $\operatorname{dpgdppc}=-4.42$ ). Other countries from the $10 \mathrm{EU}$ (i.e. RO, SK, SI) are grouped in the second cluster, with a moderate decrease of public deficit in GDP (central value of the cluster for $d b a l=0.17$ ), a high increase of the general government consolidated gross debt in GDP (central value of the cluster for the $d d e b t=2.05$ ) and the highest real GDP growth rate (central value of the cluster for the $d p g d p p c=0.66$ ). Other countries from 10EU (i.e. EE, HU, PL) are grouped in the third cluster, with a high decrease of public deficit in GDP (central value of the cluster for $d b a l=0.34$ ), a relatively small decrease of the general government consolidated gross debt in GDP (central value of the cluster for the $d d e b t=$ 
-0.24) and a high improvement of economic growth (central value of the cluster for the $\operatorname{dpg} d p p c=0.51$ ). BG (which is the only country in its cluster) is characterized by the highest average change in balance $=0.45$, the highest improvement in debt $=-6.57$ but a worsened situation of economic growth, a decrease of GDP per capita $=-3.18$.

Is there a necessity for fiscal adjustment in ex-communist countries? In the current financial and economical context, most of the countries have to apply strategies for fiscal adjustment. What it is different in transition countries from the fiscal adjustment point of view is the characteristics of the fiscal system: the magnitude of the fiscal adjustment needed to stabilize macroeconomic environment, the expenditures' composition that has to be changed, the revenues' composition that has to be converted to the indirect tax regime, the weak institutional context regarding the spending management system, the necessity of ensuring proper correlation of the negative effects of increasing taxation with the benefits of the expenditures involved in implementing programs.

In the next table there are registered the periods in which there are signs of fiscal adjustment necessity, respectively periods with budget deficit greater than $3 \%$ of GDP and public debt greater than $60 \%$ of GDP.

Table 3. Need for fiscal adjustment-signalled through balance (need_deficit) and through general government consolidated gross debt (need_debt)

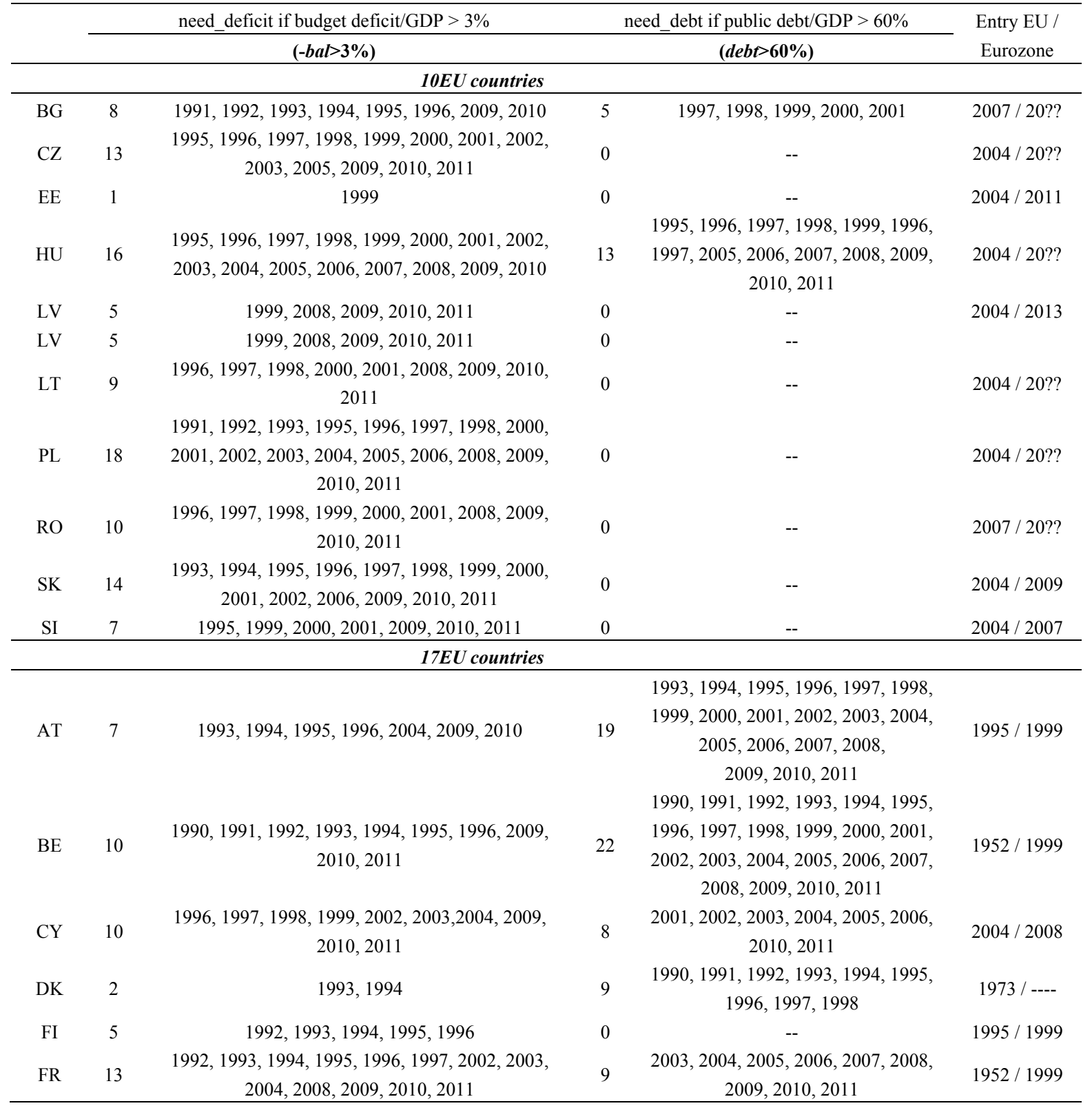




\begin{tabular}{|c|c|c|c|c|c|}
\hline $\mathrm{DE}$ & 10 & $\begin{array}{c}1993,1995,1996,2001,2002,2003,2004,2005 \\
2009,2010\end{array}$ & 13 & $\begin{array}{c}1998,1999,2000,2002,2003,2004, \\
2005,2006,2007,2008,2009,2010, \\
2011\end{array}$ & $1952 / 1999$ \\
\hline EL & 22 & $\begin{array}{l}1990,1991,1992,1993,1994,1995,1996,1997, \\
1998,1999,2000,2001,2002,2003,2004,2005, \\
2006,2007,2008,2009,2010,2011\end{array}$ & 22 & $\begin{array}{l}1990,1991,1992,1993,1994,1995, \\
1996,1997,1998,1999,2000,2001, \\
2002,2003,2004,2005,2006,2007, \\
2008,2009,2010,2011\end{array}$ & $1981 / 2001$ \\
\hline IE & 4 & $2008,2009,2010,2011$ & 11 & $\begin{array}{c}1990,1991,1992,1993,1994,1995 \\
1996,1997,2009,2010,2011\end{array}$ & $1973 / 1999$ \\
\hline IT & 16 & $\begin{array}{l}1990,1991,1992,1993,1994,1995,1996,2001, \\
2002,2003,2004,2005,2006,2009,2010,2011\end{array}$ & 22 & $\begin{array}{l}\text { 1990, 1991, 1992, 1993, 1994, 1995, } \\
\text { 1996, 1997, 1998, 1999, 2000, 2001, } \\
2002,2003,2004,2005,2006,2007, \\
2008,2009,2010,2011\end{array}$ & $1952 / 1999$ \\
\hline LU & 0 & --- & 0 & -- & $1952 / 1999$ \\
\hline MT & 13 & $\begin{array}{c}1995,1996,1997,1998,1999,2000,2001,2002, \\
2003,2004,2008,2009,2010\end{array}$ & 10 & $\begin{array}{c}2001,2003,2004,2005,2006,2007, \\
2008,2009,2010,2011\end{array}$ & $2004 / 2008$ \\
\hline NL & 8 & 1990, 1992, 1994, 1995, 2003, 2009, 2010, 2011 & 13 & $\begin{array}{c}1996,1997,1998,1999,2009,2010, \\
2011\end{array}$ & $1952 / 1999$ \\
\hline PT & 22 & $\begin{array}{l}1990,1991,1992,1993,1994,1995,1996,1997, \\
1998,1999,2000,2001,2002,2003,2004,2005, \\
2006,2007,2008,2009,2010,2011\end{array}$ & 8 & $\begin{array}{c}2005,2006,2007,2008,2009,2010, \\
2011\end{array}$ & $1986 / 1999$ \\
\hline ES & 8 & 1995, 1996, 1997, 1998, 2008, 2009, 2010, 2011 & 7 & $\begin{array}{c}1995,1996,1997,1998,1999,2010, \\
2011\end{array}$ & $1986 / 1999$ \\
\hline SE & 4 & $1993,1994,1995,1996$ & 6 & 1994, 1995, 1996, 1997, 1998, 1999 & $1995 /----$ \\
\hline UK & 13 & $\begin{array}{c}1991,1992,1993,1994,1995,1996,2004,2005 \\
2006,2008,2009,2010,2011\end{array}$ & 3 & $2009,2010,2011$ & $1973 /$---- \\
\hline
\end{tabular}

The need for fiscal adjustments signalled through public budget deficit is greater in ex-communist countries comparing with the developed countries-for $10 \mathrm{EU} 46 \%$ is the proportion of the cases in which the budget deficit is greater than $3 \%$ from GDP, while for $17 \mathrm{EU}$ the proportion is $43 \%$. PL is the country from the $10 \mathrm{EU}$ which has the signals of the need for fiscal adjustments in the majority of the years, while EE was facing the deficit $>3 \%$ only in 1999. Most of the countries respected the restriction for the budget deficit in the year of joining EU. This fiscal problem is present in all of the 10EU countries, and the most frequent it is registered in PL, HU, SK, CZ, RO, and LT.

As regarding the need for fiscal adjustments signalled through general government consolidated gross debt, the situation is totally different-in ex-communist countries there are only $7.73 \%$ from the total data that represent the years with a general government consolidated gross debt greater than $60 \%$ from GDP, in the developed countries $48.66 \%$ from the total data that represent the years with a general government consolidated gross debt greater than $60 \%$ from GDP. This fiscal problem is absent in most of the 10EU countries, exceptions are HU and BG.

In the next figures, there are represented the public budget balance and the general government consolidated gross debt in GDP for the 10EU countries, in order to emphasize the need for fiscal adjustment in the excommunist countries. The green dots represent situations in which there are respected both the budget and debt limits; the orange dots represent situations in which one rule is not respected, and red dots represent situations when both rules are violated. 
www.ccsenet.org/ijef

International Journal of Economics and Finance

Vol. 7, No. 7; 2015
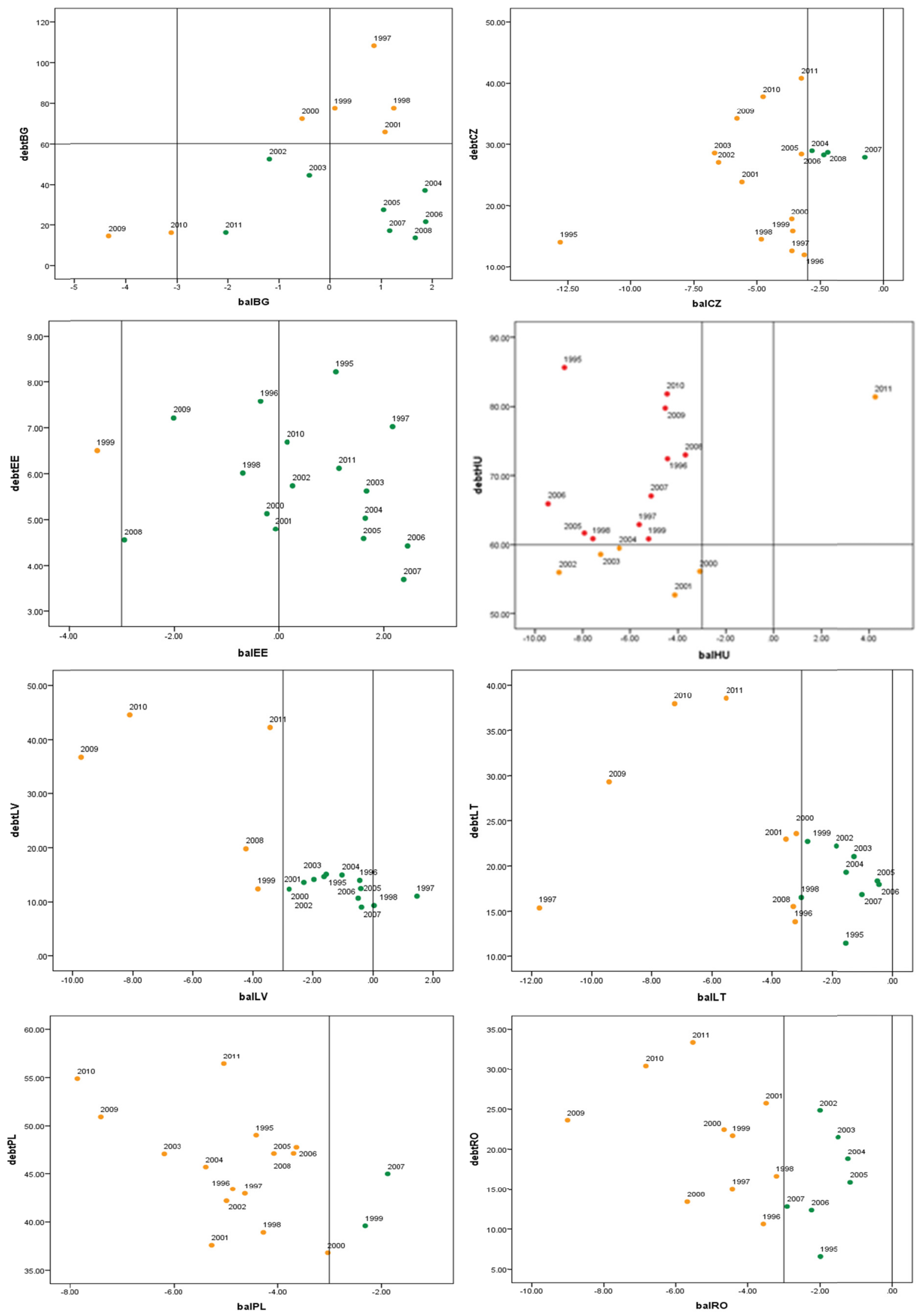

146 

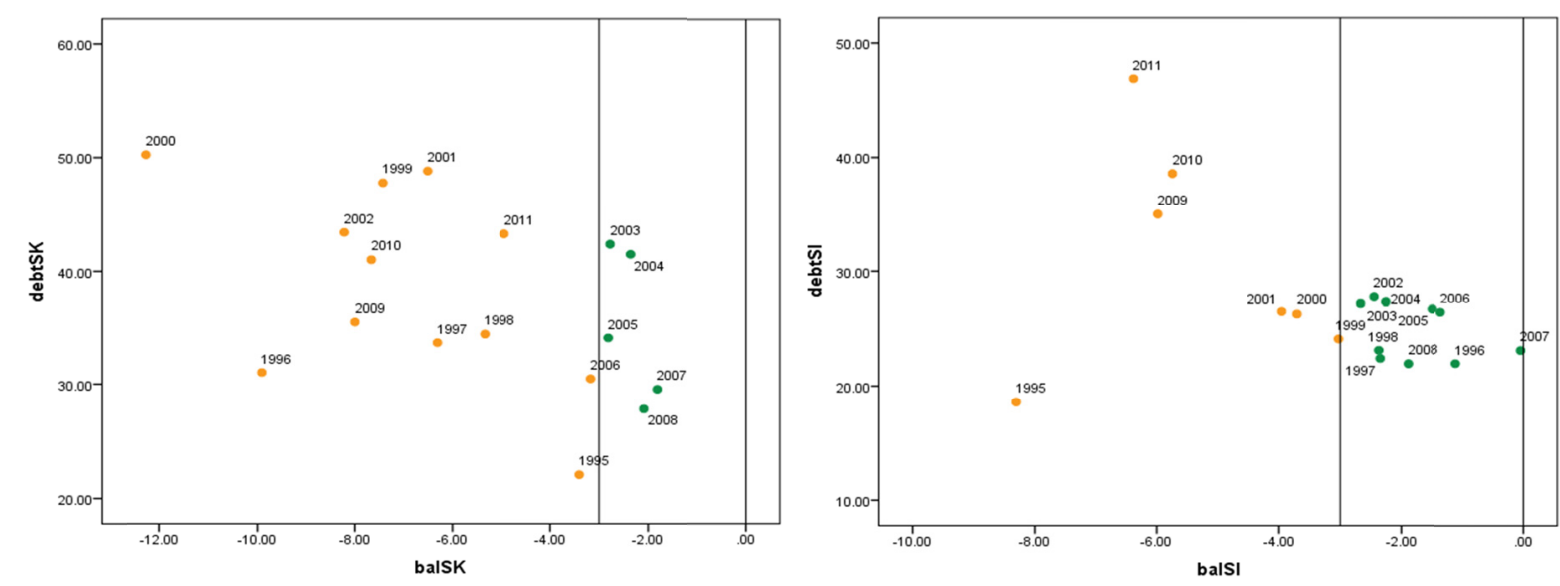

Figure1. Balance and debt in 10EU (average values for each country)

For every country, in the period 1990-2011, there are identified the fiscal adjustment episodes. The applied methodology implies to determine the type of fiscal policy, depending on the values of fiscal impulse (changes of public budget deficit $=-$ size):

(a) very relaxed (very expansionary), if fiscal impulse is greater than $1.5 \%$,

(b) relaxed, if fiscal impulse is in the range $(+0.5 \% ;+1.5 \%)$;

(c) neutral if the fiscal impulse is in the range $(-0.5 \%$; $+0.5 \%)$;

(d) restrictive (moderate adjustments), if fiscal impulse is in the range $(-1.5 \% ;-0.5 \mathrm{pp})$;

(e) very restrictive (strong adjustments), if fiscal impulse is less than $-1.5 \%$.

The next table contains information about the fiscal policy stance in $10 \mathrm{EU}$ and $17 \mathrm{EU}$, according to the previous classification.

Table 4. Stance of fiscal policy in European Union countries-1990-2011

\section{EU countries}

\begin{tabular}{|r|r|r|r|r|r|r|r|r|r|r|}
\hline & BG & CZ & EE & HU & LV & LT & PL & RO & SK & SI \\
\hline 1991 & a & a & a & a & b & a & a & a & a & a \\
\hline 1992 & e & a & a & a & a & a & e & a & a & a \\
\hline 1993 & a & a & a & a & e & a & e & a & a & a \\
\hline 1994 & e & a & a & a & a & c & e & a & e & a \\
\hline 1995 & a & a & a & a & c & b & a & a & e & a \\
\hline 1996 & a & e & b & e & d & a & c & a & a & e \\
\hline 1997 & e & c & e & b & e & a & c & b & e & b \\
\hline 1998 & c & b & a & a & b & e & c & d & d & c \\
\hline 1999 & b & d & a & e & a & c & e & b & a & b \\
\hline 2000 & b & c & e & e & d & c & b & c & a & b \\
\hline 2001 & e & a & c & b & d & c & a & d & e & c \\
\hline 2002 & a & b & c & a & c & e & c & d & a & e \\
\hline 2003 & d & c & d & e & d & d & b & d & e & c \\
\hline 2004 & e & e & c & d & d & c & d & c & c & c \\
\hline 2005 & b & c & c & b & d & d & d & c & c & d \\
\hline 2006 & d & d & d & a & c & c & c & b & c & c \\
\hline 2007 & b & e & c & e & c & b & e & b & d & d \\
\hline 2008 & d & b & a & d & a & a & a & a & c & a \\
\hline 2009 & a & a & d & b & a & a & a & a & a & a \\
\hline 2010 & d & d & e & c & e & e & c & e & c & c \\
\hline 2011 & d & e & d & e & e & e & e & d & e & b \\
\hline
\end{tabular}




\section{$17 E U$ countries}

\begin{tabular}{|c|c|c|c|c|c|c|c|c|c|c|c|c|c|c|c|c|c|}
\hline & $\mathrm{AT}$ & $\mathrm{BE}$ & $\mathrm{CY}$ & $\mathrm{DK}$ & FI & FR & $\mathrm{DE}$ & EL & IE & IT & LU & MT & NL & $\mathrm{PT}$ & ES & $\mathrm{SE}$ & UK \\
\hline 1991 & $\mathrm{c}$ & $\mathrm{b}$ & $\mathrm{a}$ & $\mathrm{a}$ & a & $\mathrm{b}$ & $\mathrm{a}$ & $\mathrm{e}$ & $\mathrm{c}$ & $\mathrm{c}$ & $\mathrm{a}$ & $\mathrm{a}$ & $\mathrm{e}$ & $\mathrm{b}$ & $\mathrm{a}$ & $\mathrm{a}$ & $\mathrm{b}$ \\
\hline 1992 & d & $\mathrm{b}$ & $\mathrm{a}$ & $\mathrm{c}$ & $\mathrm{a}$ & a & $\mathrm{c}$ & $\mathrm{b}$ & $\mathrm{c}$ & d & $\mathrm{b}$ & $\mathrm{a}$ & $\mathrm{b}$ & e & $\mathrm{a}$ & $\mathrm{a}$ & $\mathrm{a}$ \\
\hline 1993 & a & d & $\mathrm{a}$ & $\mathrm{b}$ & a & a & $\mathrm{b}$ & $b$ & $\mathrm{c}$ & $\mathrm{c}$ & $\mathrm{e}$ & $\mathrm{a}$ & d & a & $\mathrm{a}$ & $\mathrm{a}$ & $\mathrm{b}$ \\
\hline 1994 & $\mathrm{c}$ & $\mathrm{e}$ & a & $\mathrm{c}$ & e & d & $\mathrm{d}$ & $\mathrm{e}$ & $\mathrm{d}$ & d & d & a & $b$ & c & $\mathrm{a}$ & e & d \\
\hline 1995 & $\mathrm{~b}$ & d & $\mathrm{a}$ & $\mathrm{c}$ & d & c & $\mathrm{a}$ & b & $\mathrm{c}$ & $\mathrm{e}$ & $\mathrm{c}$ & $\mathrm{a}$ & $\mathrm{a}$ & $\mathrm{e}$ & $\mathrm{a}$ & $\mathrm{e}$ & d \\
\hline 1996 & e & d & $\mathrm{a}$ & $\mathrm{d}$ & e & d & $\mathrm{e}$ & e & $\mathrm{e}$ & $\mathrm{c}$ & $b$ & a & $\mathrm{e}$ & d & $\mathrm{e}$ & $\mathrm{e}$ & e \\
\hline 1997 & e & $\mathrm{e}$ & $\mathrm{a}$ & $\mathrm{d}$ & $\mathrm{e}$ & d & $\mathrm{d}$ & d & $\mathrm{e}$ & $\mathrm{e}$ & $\mathrm{e}$ & d & d & d & d & $\mathrm{e}$ & e \\
\hline 1998 & $\mathrm{~b}$ & d & d & $\mathrm{d}$ & $\mathrm{e}$ & d & $\mathrm{c}$ & e & $\mathrm{d}$ & $\mathrm{c}$ & $\mathrm{c}$ & $\mathrm{a}$ & $\mathrm{c}$ & c & $\mathrm{d}$ & e & $\mathrm{e}$ \\
\hline 1999 & c & $\mathrm{c}$ & $\mathrm{c}$ & $\mathrm{d}$ & c & d & $\mathrm{d}$ & d & $\mathrm{c}$ & $\mathrm{d}$ & $\mathrm{c}$ & e & d & d & $\mathrm{e}$ & $\mathrm{c}$ & d \\
\hline 2000 & d & d & $\mathrm{e}$ & $\mathrm{d}$ & e & c & $\mathrm{e}$ & $b$ & $\mathrm{e}$ & d & $\mathrm{e}$ & d & e & c & $\mathrm{c}$ & e & $\overline{\mathrm{e}}$ \\
\hline 2001 & e & $\mathrm{c}$ & $\mathrm{c}$ & $b$ & a & c & $\mathrm{a}$ & $b$ & $\mathrm{a}$ & $\mathrm{a}$ & c & $\mathrm{b}$ & a & $\mathrm{b}$ & $\mathrm{c}$ & $\mathrm{a}$ & $\mathrm{a}$ \\
\hline 2002 & $\mathrm{~b}$ & $\mathrm{~b}$ & $\mathrm{a}$ & $b$ & $\mathrm{~b}$ & a & $b$ & $\mathrm{c}$ & $b$ & $\mathrm{c}$ & $\mathrm{a}$ & d & $\mathrm{a}$ & d & $\mathrm{c}$ & $\mathrm{a}$ & $\mathrm{a}$ \\
\hline 2003 & $\mathrm{~b}$ & $\mathrm{c}$ & $\mathrm{a}$ & $\mathrm{c}$ & $\mathrm{a}$ & $\mathrm{b}$ & $\mathrm{c}$ & $b$ & $\mathrm{~d}$ & $\mathrm{c}$ & $\mathrm{a}$ & $\mathrm{a}$ & $b$ & c & $\mathrm{c}$ & $\mathrm{c}$ & $\mathrm{b}$ \\
\hline 2004 & a & c & $\mathrm{e}$ & $\mathrm{e}$ & $\mathrm{c}$ & c & $\mathrm{c}$ & $\mathrm{a}$ & $\mathrm{d}$ & $\mathrm{c}$ & $\mathrm{a}$ & $\mathrm{e}$ & d & $\mathrm{c}$ & $\mathrm{c}$ & $\mathrm{e}$ & $\mathrm{c}$ \\
\hline 2005 & e & $\mathrm{a}$ & $\mathrm{e}$ & $\mathrm{e}$ & c & d & $\mathrm{c}$ & $\mathrm{e}$ & $\mathrm{c}$ & $\mathrm{b}$ & d & $\mathrm{e}$ & d & $\mathrm{a}$ & $\mathrm{d}$ & $\mathrm{e}$ & $\mathrm{c}$ \\
\hline 2006 & c & $\mathrm{e}$ & d & $\mathrm{c}$ & d & d & e & $\mathrm{c}$ & d & d & d & $\mathrm{c}$ & d & e & $\mathrm{d}$ & $\mathrm{c}$ & $\mathrm{d}$ \\
\hline 2007 & d & $\mathrm{c}$ & $\mathrm{e}$ & $\mathrm{c}$ & d & c & $\mathrm{e}$ & $b$ & $\mathrm{a}$ & $\mathrm{e}$ & $\mathrm{e}$ & c & $\mathrm{c}$ & d & $\mathrm{c}$ & d & $\mathrm{c}$ \\
\hline 2008 & c & $\mathrm{b}$ & a & $\mathrm{a}$ & $b$ & $\mathrm{~b}$ & $\mathrm{c}$ & $\mathrm{a}$ & $\mathrm{a}$ & $b$ & $\mathrm{c}$ & a & $\mathrm{c}$ & c & a & $\mathrm{b}$ & a \\
\hline 2009 & $\mathrm{a}$ & $\mathrm{a}$ & $\mathrm{a}$ & $\mathrm{a}$ & $\mathrm{a}$ & $\mathrm{a}$ & $\mathrm{a}$ & $\mathrm{a}$ & $\mathrm{a}$ & $\mathrm{a}$ & $\mathrm{a}$ & d & $\mathrm{a}$ & $\mathrm{a}$ & $\mathrm{a}$ & $\mathrm{a}$ & $\mathrm{a}$ \\
\hline 2010 & c & $\mathrm{e}$ & d & $\mathrm{c}$ & $\mathrm{c}$ & c & $b$ & $\mathrm{e}$ & $\mathrm{a}$ & d & $\mathrm{c}$ & c & d & c & $\mathrm{d}$ & d & $\mathrm{d}$ \\
\hline 2011 & e & $\mathrm{c}$ & b & $\mathrm{d}$ & e & e & $\mathrm{e}$ & d & $\mathrm{e}$ & d & d & d & d & e & $\mathrm{c}$ & $\mathrm{c}$ & $\mathrm{e}$ \\
\hline
\end{tabular}

Note. In the previous table there are used the following:

- a", b", c", d", e" represent the stance of fiscal policy.

- the colours are used just for emphasis the situations: pink is used for the very relaxed fiscal policy, blue is used for the fiscal adjustments.

As the previous tables show, the situation on fiscal adjustments in EU10 is the following:

- $\quad$ in the period 1991-1995 there were few fiscal adjustment, even the signals were that the consolidation was needed (exceptions are BG, LV, PL, SK);

- after 1996 most of the periods are characterized by fiscal adjustments (moderate or strong), exceptions are the period 2008-2009 due to the effects of the financial crises, which deteriorate the fiscal position for most of the $10 \mathrm{EU}$.

In the next table, there are registered the averages for public budget balance, general government consolidated gross debt, public expenditures and revenues (values in GDP and absolute change in pp), GDP per capita in constant price at purchasing power standard in each of the five stances of fiscal policy-a-very relaxed (very expansionary), b-relaxed, c-neutral, d-restrictive (moderate adjustments), and e-very restrictive (strong adjustments).

Table 5. Average values for fiscal and economic growth indicators in the case of each type of fiscal policy

\begin{tabular}{|c|c|c|c|c|c|c|c|c|c|c|}
\hline & fiscal stance & bal & debt & $\operatorname{dexp}$ & drev & dpgdppc & outputgap & size & exp_contrib & dbal_dexp \\
\hline $10 \mathrm{EU}$ & 69 & -6.16 & 30.51 & 2.89 & -0.8 & -7.84 & 1.56 & -3.84 & 0.74 & 0.77 \\
\hline \multicolumn{11}{|l|}{ b } \\
\hline $10 \mathrm{EU}$ & 26 & -2.69 & 33.31 & 0.73 & -0.27 & -1.17 & 0.69 & -0.99 & 0.91 & 0.6 \\
\hline \multicolumn{11}{|l|}{ c } \\
\hline $10 \mathrm{EU}$ & 41 & -2.57 & 27.42 & -0.01 & -0.03 & -0.42 & 0.81 & -0.03 & 2.77 & 0.58 \\
\hline $17 \mathrm{EU}$ & 85 & -1.98 & 63.1 & -0.06 & -0.03 & 1.49 & 0.47 & 0.03 & 0.57 & 0.52 \\
\hline \multicolumn{11}{|l|}{ d } \\
\hline $10 \mathrm{EU}$ & 33 & -1.92 & 24.26 & -1.14 & -0.15 & 1.69 & 0.4 & 0.99 & 1.17 & 0.79 \\
\hline $17 \mathrm{EU}$ & 69 & -2.19 & 68.29 & -2 & 0.79 & 1.96 & -0.11 & 2.8 & 0.7 & 0.71 \\
\hline
\end{tabular}


Comparing the situations between $10 \mathrm{EU}$ and 17EU, there could be observed the differences in fiscal policies:

In the case of the very relaxed or very expansionary fiscal policy, "a", the deteriorated public budget deficit is greater in 10EU (average value of $b a l=-6.16$ in $10 \mathrm{EU} /-4.81$ in 17EU), which is also sustain by the size of the adjustment (average value of size $=-3.84$ in 10EU / -3.77 in 17EU) the increase and the level of the general government consolidated gross debt are greater in EU17 (average value of debt $=30.51$ in 10EU / 55.50 in $17 \mathrm{EU}$ ), the increase of public expenditure is smaller in EU10 (average value of dexp $=2.89$ in 10EU / 3.06 in $17 \mathrm{EU}$ ); public revenues decrease is greater in $10 \mathrm{EU}$ (average value of drev $=-0.80 \mathrm{in} 10 \mathrm{EU} /-0.71$ in 17EU). As a conclusion, the "relaxation" of fiscal policy had been done only in a very small proportion through the decrease of public revenues (average values of exp_contrib $=74 \%$ for $10 \mathrm{EU} / 78 \%$ for 17EU), most of it had concerned the increase of public expenditures. Nevertheless, the economic growth had declined, the decrease of GDP per capita in constant price at purchasing power standard is significantly higher in 10EU ( $d p g d p p c=-7.84$ in 10EU / -0.02 in 17EU), the output gap is positive in 10EU but negative in 17EU, which sustains that the current GDP in ex-communist countries was above the potential GDP.

In the case of the relaxed fiscal policy, "b", the deteriorated public budget deficit is smaller in 10EU (average value of bal $=-2.69$ in 10EU / -3.57 in 17EU), despite the bigger increase of the budgetary deficit (size $=-0.99$ in $10 \mathrm{EU} /-0.93$ in 17EU); the general government consolidated gross debt is significantly lower in 10EU (average value of $d e b t=33.31$ in $10 \mathrm{EU} / 68.36$ in 17EU); the increase of public expenditure is smaller in EU10 (average value of $\operatorname{dexp}=0.73$ in 10EU / 0.88 in 17EU) but the public revenues decrease more 10EU (average value of drev $=-0.27$ in $10 \mathrm{EU} /-0.05$ in $17 \mathrm{EU}$ ). As a conclusion, the "relaxation" of fiscal policy had been done only in a small proportion through the decrease of public revenues (average values of exp_contrib $=91 \%$ for $10 \mathrm{EU} / 99 \%$ for 17EU), most of it had concerned the increase of public expenditures. Nevertheless, the economic growth had declined, the decrease of GDP per capita in constant price at purchasing power standard is significantly higher in $10 \mathrm{EU}$ ( $d p g d p p c=-1.17$ in 10EU / -0.26 in 17EU), the output gap is positive both in 10EU and 17EU, which sustains that the current GDP in ex-communist countries and the developed countries was above the potential GDP.

In the case of the neutral fiscal policy, " $\mathrm{c}$ ", the public budget deficit is bigger in 10EU (average value of bal = -2.57 in $10 \mathrm{EU} /-1.98$ in 17EU), and the budget deficit is increased in 10EU, while in 17EU is decreased (size = -0.03 in $10 \mathrm{EU} / 0.03$ in 17EU); the general government consolidated gross debt is significantly lower in 10EU (average value of $d e b t=27.42$ in $10 \mathrm{EU} / 63.10$ in 17EU); both the public expenditure and public revenue decrease, but insignificantly. Despite the neutrality of fiscal policy, the economic growth is negatively influenced in $10 \mathrm{EU}$ and positively in $17 \mathrm{EU}$ ( $d p g d p p c=-0.42$ in $10 \mathrm{EU} / 1.49$ in $17 \mathrm{EU}$ ), the output gap is positive in both samples.

In the case of the restrictive fiscal policy or moderate adjustments, "d", the deteriorated public budget deficit is smaller in 10EU (average value of $b a l=-1.92$ in $10 \mathrm{EU} /-2.49$ in 17EU), but the increase in public budget balance is greater in 10EU (average value of size $=0.99$ in $10 \mathrm{EU} / 0.95$ in 17EU); the level of the general government consolidated gross debt are greater in (average value of $d e b t=24.26 \mathrm{in} 10 \mathrm{EU} / 65.45 \mathrm{in} 17 \mathrm{EU}$ ); the decrease of public expenditures is greater in 10EU (average value of dexp $=-1.14$ in $10 \mathrm{EU} /-0.62$ in 17EU), the fiscal adjustments is supported also by the increase of public revenue only in 17EU (drev $=-0.15$ in 10EU / 0.33 in 17EU). The adjustment through the decrease of public expenditures has a significant role in decreasing deficit (exp_contrib $=117 \%$ in 10EU / 66\% in 17EU). The influence of the fiscal policy adjustments on real economy was positive, the economic growth had increased, GDP per capita in constant price at purchasing power standard had increased (average value of $d g d p p c=1.69 \mathrm{in} \mathrm{10EU} \mathrm{/} 1.89$ in 17EU), and also the output gap is positive.

In the case of the very restrictive fiscal policy or strong adjustments, "e", the deteriorated public budget deficit is greater in 10EU (average value of $b a l=-2.83$ in $10 \mathrm{EU} /-2.19$ in 17EU), but an important observation is that the increase in public budget balance is greater in 10EU (average value of size $=4.35$ in $10 \mathrm{EU} / 2.80$ in 17EU); the level of the general government consolidated gross debt are greater in EU17 but the average value in 10EU is significantly higher than in the other stances of fiscal policy (average value of $d e b t=40.01$ in 10EU / 68.29 in $17 \mathrm{EU}$ ); the decrease of public expenditures is greater in 10EU (average value of dexp $=-3.80$ in $10 \mathrm{EU} /-2$ in $17 \mathrm{EU}$ ), while the increase in public revenues is smaller in $10 \mathrm{EU}$ (average value of drev $=0.41$ in $10 \mathrm{EU},=0.79$ in 17EU). As a conclusion, the fiscal adjustments had been done only in a very small proportion through the increase of public revenues, most of it had concerned the decrease of public expenditures (average value of exp_contrib $=86 \%$ in $10 \mathrm{EU} / 70 \%$ in $17 \mathrm{EU}$ ). Nevertheless, the influence of the fiscal policy on real economy was positive, economic growth had increased, the change of GDP per capita in constant price at purchasing power standard is positive (average value of $d g d p p c=0.18$ in 10EU /1.96 in 17EU), but the output gap is 
negative in both sample, which sustains that the current GDP in ex-communist countries and the developed countries was below the potential GDP.

In the next table there are registered the number of episodes for the very restrictive fiscal policy and their structure depending on their success, expansionary characteristics and the expenditure contribution for fiscal position.

Table 6. Fiscal adjustment-success, gradual, expenditure-based

\begin{tabular}{|c|c|c|c|c|c|c|c|c|}
\hline \multirow[b]{2}{*}{ success } & \multirow[b]{2}{*}{ gradual } & \multirow[b]{2}{*}{ dbal_dexp } & \multicolumn{6}{|c|}{ strong adjustments } \\
\hline & & & \multicolumn{2}{|c|}{ EU27 } & \multicolumn{2}{|c|}{$10 \mathrm{EU}$} & \multicolumn{2}{|c|}{$17 \mathrm{EU}$} \\
\hline & & & 110 & & & $37,27 \%)$ & & $62,73 \%)$ \\
\hline 1 & & & 99 & $-90 \%$ & 35 & $(85,37 \%)$ & 64 & $(92,75 \%)$ \\
\hline \multirow[t]{5}{*}{0} & & & 11 & $-10 \%$ & 6 & $(14,63 \%)$ & 5 & $(7,25 \%)$ \\
\hline & 1 & & 65 & $(59,09 \%)$ & 20 & $(48,78 \%)$ & 45 & $(65,22 \%)$ \\
\hline & 0 & & 45 & $(40,91 \%)$ & 21 & $(51,22 \%)$ & 24 & $(34,78 \%)$ \\
\hline & & 1 & 81 & $(73,64 \%)$ & 32 & $(78,05 \%)$ & 49 & $(71,01 \%)$ \\
\hline & & 0 & 29 & $(26,36 \%)$ & 9 & $(21,95 \%)$ & 20 & $(28,99 \%)$ \\
\hline
\end{tabular}

From the total number of fiscal adjustment episodes, the success rate is lower in 10EU comparing with 17EU (85.37\% situations, the fiscal adjustment led to a deficit lower than 3\% to GDP). Regarding the gradualism of the fiscal adjustment, $48.78 \%$ from the total adjustments were made gradually in $10 \mathrm{EU}$, while de rate in $17 \mathrm{EU}$ is $65.22 \%$. Considering the composition of the fiscal adjustments, $78 \%$ were obtained through a more impact of the expenditures reduction in 10EU, comparing with $71 \%$ in $17 \mathrm{EU}$.

In the case of transition countries, fiscal adjustment process has certain characteristics-fiscal policy must generate a favourable environment for the development of economic growth while stimulating private sector development through reorganization of revenues and expenditures. Fiscal adjustment may have features for countries in transition to developed countries due to differences in the initial conditions.

The rest of the paper is concentrated only on the fiscal adjustment episodes, in the 10EU countries and 17EU countries.

In order to determine the determinant factors that influence the the probability that fiscal adjustment generates a sustainable reduction in the public budget deficit-the success' probability of the fiscal adjustment, $\mathrm{P}$, we use a reduced form model "logit":

$$
\log \frac{P_{t}}{1-P_{t}}=\alpha_{0}+\alpha_{1} \cdot x_{1}+\ldots \ldots+\alpha_{n} \cdot x_{n}
$$

This model is estimated using 41 data which represent the fiscal adjustments in 10EU countries, considering different sets of explanatory variables. The analysed period for these estimations is 1996-2011, because some of the explanatory variables were not available for the period 1990-1995. In order to compare the characteristics of the fiscal adjustments in 10EU with 17EU, there are also conducted logit models for 17EU sample, which contains 69 data of fiscal adjustment episodes. The results are presented in the following table.

Table 7. Logit models-determinant factors for the fiscal adjustment's success

\begin{tabular}{|c|c|c|c|c|c|c|c|c|}
\hline & \multicolumn{4}{|c|}{ EU10 } & \multicolumn{4}{|c|}{ EU17 } \\
\hline & Logit 1 & Logit 2 & Logit 3 & Logit 4 & Logit 5 & Logit 6 & Logit 7 & Logit 8 \\
\hline$c$ & -0.5 & -0.47 & 8.16 & 0.17 & 1.05 & 1.44 & -5.18 & 0.75 \\
\hline need_debt & & & & & 0.52 & 0.61 & & \\
\hline need_deficit & 1.7 & 1.82 & & & 1.93 & 1.91 & & \\
\hline dbal_dexp & & -0.61 & -1.14 & & & & -0.71 & \\
\hline \multicolumn{9}{|l|}{ bal } \\
\hline rev & & & $-0.81 * * *$ & & & & -0.16 & \\
\hline $\exp$ & & & $0.58 * * *$ & & & & $0.33 * * *$ & \\
\hline drev & 0.38 & & & & 0.25 & & & \\
\hline $\operatorname{dexp}$ & -0.45 & & & & -0.12 & & & \\
\hline
\end{tabular}




\begin{tabular}{lcccccc}
\hline dbal=size & 0.47 & 0.99 & 1.11 & 0.15 & 0.1 & -0.61 \\
exp_contrib & 0.29 & 0.33 & -0.93 & -0.55 & 0.22 & 0.02 \\
dpgdppc & & & 0.11 & & $0.03 * * *$ \\
debt & & & -0.005 & & 0.1457 & 0.2624 \\
McFadden $\boldsymbol{R}^{2}$ & 0,2146 & 0.2 & 0.3621 & 0.201 & 0.141 & 0.1008 \\
\hline
\end{tabular}

Note. $* * *$ significance level $10 \%$.

Regarding the determinants of fiscal adjustment success, the dummy variables need_deficit, need_debt have positive effects-the positive coefficients of the need_deficit and need_debt in models Logit 1, Logit 2, Logit 5, Logit 6, which sustain the effectiveness of the fiscal consolidation when it is needed.

The structure (composition) of the fiscal adjustment-the results sustain the conclusion that the adjustments based more on expenditure cuts negatively influence the adjustment success-the negative coefficient of the dummy variable dbal_dexp in models Logit 2, 3, and 7.

Analyzing the effect of the public revenue-a high level of public revenue diminishes the probability of successthe negative coefficient of the rev variable in models Logit3, Logit 7 (and also the coefficient is greater for the case of 10EU), while the increase of the revenue implies a high probability of success-the positive coefficient of the drev variable in models Logit 1, Logit 5 (the coefficient is greater for the case 10EU).

Analyzing the impact of the public expenditures, a high level of expenditures and a decrease of this level increase the probability of the consolidation process-the positive coefficient of the exp variable in models Logit 3 , Logit 7 (the coefficient is greater for the case of 10EU) and the negative coefficient of the $\operatorname{dexp}$ in models Logit 1, Logit 5 (the coefficient is greater for the case of 10EU).

The size of the adjustment has a positive influence on the probability of success, which sustain that large fiscal consolidation are lasting and generate improvement in budgetary conditions-the positive coefficient of the size variable in models Logit 2, Logit 3, Logit 4, Logit 5, Logit 7, and Logit 8. The coefficients obtained for the $10 \mathrm{EU}$ sample are greater than those obtained for the 17EU sample.

The proportion of the adjustment obtained by the expenditure reduction has an ambiguous impact on the consolidation success-the positive and the negative coefficient of the exp_contrib variable in the models Logit 2, Logit 3, Logit 4, Logit 5, Logit 7, and Logit 8. The effects are more significant in the 10EU sample.

The change of the GDP per capita has a positive effect on the consolidation success-the positive coefficients of the $d p g d p p c$ variable in models Logit 4, Logit 8, which support the hypothesis that stimulating the development of the real economy generates a sustainability of the fiscal adjustment process. The effects are more significant in $10 \mathrm{EU}$ sample.

The general government consolidated gross debt in GDP has a different impact on the consolidation probability of success in the 10EU and 17EU, but the coefficients are very small-models Logit 4, Logit 8.

\section{Conclusions}

Our analysis proves several common characteristics of the ex-communist countries from European Union such as: a relatively high level of public deficit in GDP, but a low level of general government consolidated gross debt in GDP and the small level of GDP per capita in constant prices at purchasing power standard compared with the other countries from UE27. The level of budget deficit higher than 3\% of GDP (maximum level of budget deficit required by Maastricht criteria) justifies the need for fiscal adjustments. More or less, in the current financial and economical context, all countries face the challenges of fiscal adjustment, but what it is different in ex-communist countries from the fiscal adjustment point of view is the characteristics of the fiscal system: the magnitude of the fiscal adjustment needed to stabilize macroeconomic environment, the expenditures' composition that has to be changed, the revenues' composition that has to be converted to the indirect tax regime, the weak institutional context regarding the spending management system, the necessity of ensuring proper correlation of the negative effects of increasing taxation with the benefits of the expenditures involved in implementing programs.

During the period 1990-2011, for ex-communist countries UE10 there was given 107 periods with signals for the need of fiscal adjustments, $84 \%$ of them signalled through budget balance, $6 \%$ signalled through general government consolidated debt and 10\% signalled through both indicators. For the UE17, there were 238 periods with signals for the need of fiscal adjustment, $24 \%$ signalled through budget balance, 30\% through general government consolidated debt, and $46 \%$ through both indicators. As we can observe the ex-communist countries 
cross difficult periods related more to budget balance, and not to government debt (except of Hungary and Bulgaria) even if the growth rate of public debt is rising for the majority of ex-communist countries.

Analyzing the situations of fiscal adjustment episodes in UE10 (the ex-communist countries) we can conclude that $85 \%$ of them were considered as being successful fiscal adjustment episodes (respectively one year after the adjustment the deficit remains below the deficit from the previous year of the fiscal adjustment). So the success rate for 10UE is much smaller than for the 17UE where it registered the level of $93 \%$. Regarding the gradualism, only $49 \%$ of the fiscal adjustments were obtained gradually in 10EU, comparing with $65 \%$ in $17 \mathrm{EU}$, which reflects the inconsistency of the fiscal policies in ex-communist countries. Considering the composition of the fiscal adjustments, $78 \%$ were obtained through a more impact of the expenditures reduction in 10EU, comparing with $71 \%$ in $17 \mathrm{EU}$.

Also, it is important to emphasise that in the case of ex-communist countries, fiscal adjustment process has certain characteristics-fiscal policy must generate a favourable environment for the development of economic growth while stimulating private sector development through reorganization of revenues and expenditures.

Comparing the successful with the unsuccessful episodes of fiscal adjustment, there can be noticed that in the case of the first one the size of fiscal adjustment is greater, the public budget balance in GDP is greater, the general government consolidated gross debt is smaller, the public expenditure on GDP is smaller, but also the public revenue is smaller.

Regarding the determinants of fiscal adjustment success, the dummy variables need_deficit, need debt have positive effects; the structure (composition) of the fiscal adjustment-the results sustain the conclusion that the adjustments based more on expenditure cuts negatively influence the adjustment. Analyzing the effect of the public revenue and expenditure-a high level of public revenue diminishes the probability of success, while the increase of the revenue implies a high probability of success; a high level of expenditures and a decrease of this level increase the probability of the consolidation process. The size of the adjustment has a positive influence on the probability of success, which sustain that large fiscal consolidation are lasting and generate improvement in budgetary. The proportion of the adjustment obtained by the expenditure reduction has an ambiguous impact on the consolidation success. The change of the GDP per capita has a positive effect on the consolidation success, which support the hypothesis that stimulating the development of the real economy generates a sustainability of the fiscal adjustment process. The values of the coefficients are significantly higher in the case 10EU sample, which suggests bigger effects of these variable on the success' probability of the fiscal adjustment in the case 10EU.

\section{References}

Alesina, A. (2010). Fiscal adjustments: Lessons from recent history. Harvard University. Retrieved from http://www.economics.harvard.edu/faculty/alesina/files/Fiscal\%2BAdjustments_lessons.pdf

Alesina, A. (2010). My answer to the Economist. Retrieved from http://www.economics.harvard.edu/faculty/alesina/Alesina

Alesina, A., \& Ardagna, S. (2009). Large Changes In Fiscal Policy: Taxes Versus Spending. Working Paper 15438. http://dx.doi.org/10.2139/ssrn.1502862

Alesina, A., \& Ardagna, S. (2010). Large Changes in Fiscal Policy: Taxes versus Spending. NBER. http://dx.doi.org/10.1086/649828

Alesina, A., \& Perotti, R. (1995a). Fiscal Expansions and Adjustments in OECD Countries. Economic Policy, 21, 207-248. http://dx.doi.org/10.2307/1344590

Alesina, A., \& Perotti, R. (1995b). Taxation and Redistribution in an Open Economy. European Economic Review, May, 961-980. http://dx.doi.org/10.1016/0014-2921(94)00111-C

Alesina, A., \& Perotti, R. (1996). Fiscal Adjustment in OECD Countries: Composition And Macroeconomic Effects. NBER Working Papers. http://dx.doi.org/10.5089/9781451960433.001

Alesina, A., \& Perotti, R. (1997). The Welfare State and Competitiveness. American Economic Review, 87, 921-939.

Alesina, A., Ardagna, S., \& Trebbi, F. (2006). Who Adjusts and When? On the Political Economy of Stabilizations. IMF Staff Papers, Mundell-Fleming Lecture, 53, 1-49.

Alesina, A., Carloni, D., \& Lecce, G. (2011). The Electoral Consequences of Large Fiscal Adjustment. NBER Working Paper, No. 17655. 
Alesina, A., Perotti, R., \& Tavares, J. (1998). The Political Economy of Fiscal Adjustments. Brookings Papers on Economic Activity, Spring. http://dx.doi.org/10.2307/2534672

Ardagna, S. (2004). Fiscal Stabilizations: When Do They Work and Why. European Economic Review, 48(5), 1047-1074. http://dx.doi.org/10.1016/j.euroecorev.2003.09.010

Blanchard, O. (1990). Comments on Giavazzi and Pagano. NBER Macroeconomic Annual.

Broadbent, B., \& Kevin, D. (2010). Limiting the fall-out from fiscal adjustment. Goldman Sachs, Global Economics Paper 195, April.

Câmpeanu, E. (2011). Current Challenges for Fiscal and Budgetary Policies. Timisoara Journal of Economics, 3(15), 149-154.

Giavazzi, F., \& Pagano, M. (1996). Non-Keynesian Effects of Fiscal Policy Changes: International Evidence and the Swedish Experience. NBER Working Papers 5332.

Hughes, H., \& McAdam, P. (2001). Fiscal Consolidation and the Probability Distribution of Deficits: A Stochastic Analysis of the Stability Pact. Studies in Economics 0101, Department of Economics, University of Kent.

Kumar, M., Leigh, D., \& Plekhanov, A. (2007). Fiscal Adjustments: Determinants and Macroeconomic Consequences. IMF WP, 07/178.

McDermott, J., \& Wescott, R. (1996). An Empirical Analysis of Fiscal Adjustments. International Monetary Fund Staff Papers, 43(4), 725-753. http://dx.doi.org/10.2307/3867367

Mulas-Granados, C., Baldacci, E., Clements, B., \& Gupta, S. (2004). Front-Loaded or Back-Loaded Fiscal Adjustments: What Works in Emerging Market Economies? IMF Working Papers 04/157, International Monetary Fund.

Nielsen, L. (2011). Peripheral Consolidation: Probable But Painful. European Weekly Analyst, 11/25.

Obreja, B. O. L. (2011). Composition and Determinants of Fiscal Adjustment's Succes in the EU27 Context. The Review of Finance and Banking, 3(2). Retrieved from http://Rfb.Ase.RO/Articole/P2.pdf

Purfield, C. (2003). Fiscal Adjustment in Transition Countries: Evidence from the 1990s. IMF Working Paper. http://dx.doi.org/10.5089/9781451845471.001

Stehn, S. J. (2010). Squaring the Fiscal Circle: Does a Fiscal Rule Help? US Economics Analyst, July 23.

Stehn, S. J., Hatzius, J., Wilson, D., \& Carlson, S. (2011). The Speed Limit of Fiscal Consolidation. Goldman Sachs. Global Economics Paper No. 207. Retrieved from http://www.goldmansachs.com/our-thinking/topics/global-economic-outlook/speed-limit-pdf.pdf

Stoian, A. (2011). A Retrospective Approach on Government Response to Increasing Public Debt: Empirical Evidence for European Countries. Working Papers 15/2011, Universidade Portucalense.

Symansky, S., Bertolini, L., \& Razin, A. (1995). Fiscal Restructuring in the Group of Seven Major Industrial Countries in the 1990s: Macroeconomic Effects. IMF Working Papers 95/35.

Von Hagen, J., Hallett, A., \& Strauch, R. (2002). Budgetary Consolidation in Europe: Quality, Economic Conditions, and Persistence. Journal of the Japanese and International Economies, 16(4), 512-535. http://dx.doi.org/10.1006/jjie.2002.0516

\section{Copyrights}

Copyright for this article is retained by the author(s), with first publication rights granted to the journal.

This is an open-access article distributed under the terms and conditions of the Creative Commons Attribution license (http://creativecommons.org/licenses/by/3.0/). 